\title{
Діагностика та лікування хворих з абсцесами печінки
}

\author{
V. O. SHAPRYNSKYI, O. A. KAMINSKYI, V. F. BILOSHCHYTSKYI, V. M. MAKAROV \\ Vinnytsia National Medical University by M. I. Pyrohov
}

\section{DIAGNOSTICS AND TREATMENT OF PATIENTS WITH HEPAR ABSCESS}

\begin{abstract}
У статті наведено досвід лікування 66 хворих 3 абсцесами печінки (АП). 38 пацієнтів були оперовані відкритим традиційним методом, 28 - шляхом використання міні-інвазивних технологій під контролем УЗД. Значна більшість АП правої частки локалізувалась в 7, 8 сегментах, лівої частки - в 3, 4 сегментах. Об'єм рідинних утворів сягав від 1-2 мл до 1,2 л. Абсцеси печінки мали, як правило, вторинний характер. Застосування міні-інвазивних технологій є ефективним методом лікування АП, дозволяє значно зменшити частоту ускладнень, тривалість госпіталізації та якість життя хворих. Летальних наслідків не було.
\end{abstract}

The article describes the experience of treatment of 66 patients with liver abscess. 38 patients were operated using a traditional open method. 28 - minimally invasive technologies under control of ultrasonography. The majority of liver abscess of the right share was localized in $7^{\text {th }}$ and $8^{\text {th }}$ segments, the left share $-3 \mathrm{~d}$ and $4^{\text {th }}$. The volume of liquid formations ranged from 1-2 ml to 1.2 l. The liver abscess was, as a rule, secondary. The use of minimally invasive technologies is an effective method of treatment of liver abscess, it allows to significantly reduce the frequency of complications, duration of hospitalization and a quality of patient's life. Lethal cases were not recorded.

Абсцеси печінки (АП) - це надзвичайно тяжкі захворювання зі складним клінічним перебігом хвороби та високими показниками летальності. Так, летальність при АП є високою: за даними літератури, впродовж останніх 20 років при його відкритому операційному розкритті та дренуванні становить від 10 до $40 \%$, а частота післяопераційних ускладнень сягає 55 \%.

АП складають до 0,16 \% захворювань, з якими хворі госпіталізуються в хірургічні стаціонари і потребують екстреного хірургічного втручання [1, 2, 3]. Найчастіше АП утворюється як наслідок ускладнення гнійних захворювань органів черевної порожнини або внаслідок нагноєння внутрішньопечінкових гематом після травм, або як ускладнення паразитарних уражень органа (амебіаз, опісторхоз).

Останнім часом із розвитком новітніх малоінвазивних та міні-інвазивних технологій підхід до лікування АП зазнав змін, що позитивно вплинуло на результати лікування: зменшилась частота ускладнень та післяопераційна летальність, скоротився час перебування на ліжку, а також покращилась якість життя таких пацієнтів. Це стало можливим завдяки використанню черезшкірно пункційно-дренажного методу лікування під контролем УЗД. Основна ідея цього методу полягає в тому, щоб під місцевою анестезією без розтину черевної стінки видалити вміст гнійних накопичень пункційно або шляхом постановки дренажу під контролем УЗД з мінімальною травматичністю для хворого. Саме із застосуванням даної методики пов' язується надія на покращення як діагностики, так і лікування АП [4, 5, 6, 7].

Мета роботи: проаналізувати результати комплексного лікування хворих з абсцесами печінки з використанням у тому числі й міні-інвазивних втручань під контролем УЗД, оцінити переваги та адекватність цих технологій.

Нами проаналізовано результати лікування 66 хворих з АП, які перебували на стаціонарному лікуванні в клініці хірургії № 1 Вінницького національного медичного університету ім. М. І. Пирогова з 2004 до травня 2015 року. Вік хворих склав від 18 до 81 року, чоловіків - 36, жінок - 30. Одиничні абсцеси спостерігались у 50 хворих, множинні - у 16. Об'єм рідинних утворів сягав від 1-2 мл до 1200 мл. За нашими даними, гнійними накопиченнями частіше уражалась права частка печінки - у 42 пацієнтів, ліва - у 16, обидві частки - у 8. АП уражали всі сегменти, але найчастіше в правій частці це були - 7, 8 і в лівій - 3, 4 сегменти. Час від початку захворювання до госпіталізації скла- 
дав від 7 діб до 2 місяців. АП, як правило, мали вторинний характер. Серед причин треба виділити холангіогенні абсцеси, післятравматичні, нагноєні кісти і “безпричинні” абсцеси (у частини хворих не вдалось встановити причину абсцесу). Простежується деяка сезонність захворювання - частіше у весняний період.

Найбільш достовірними методами діагностики АП на сьогодні є УЗД і КТ, які майже у 100 \% випадків дають можливість правильно встановити діагноз. Лабораторна діагностика цього захворювання малоспецифічна. Вибір методу лікування АП залежав від локалізації гнійного вогнища, його розмірів, конфігурації, наявності внутрішніх перегородок, а також від віку хворого, супутніх ускладнень (холангіти, печінкова недостатність, сепсис). Відкритим способом оперовано 38 пацієнтів, 3 них 5 хворих з множинними АП. Після верхньосерединної лапаротомії порожнину гнояка розкривали, санували, вміст брали на бактеріологічне дослідження. Дренували саму порожнину гнояка, піддіафрагмальний простір чи підпечінковий. У 8 пацієнтів із тяжкою супутньою патологією (холангіт, печінкова недостатність) проводили виділення круглої зв'язки печінки та катетеризацію печінкової артерії з наступним підведенням антибіотиків. У післяопераційному періоді абсцес через дренажі санували розчином антисептиків, у міру зменшення виділень з них дренажі поступово видаляли.

Летальних наслідків не було, всі пацієнти видужали. Серед ускладнень переважали серозногнійні ускладнення післяопераційної рани і незначна кровотеча в 1-го пацієнта через дренаж.

Пункції АП виконували під контролем УЗД, 28 пацієнтам із застосуванням доплерографії (для вибору “безпечного місця”) зі стандартних і нестан-

\section{СПИСОК ЛІТЕРАТУРИ}

1. Альперович Б. И. Хирургия печени / Б. И. Альперович. М. : ГЭОТАР-медиа, 2013. - С. 347.

2. Ахоладзе Г. Г. Холангиогенные абцессы печени / Г. Г. Ахоладзе, И. Ю. Церетели // Анналы хирургической гепатологии. - Т. II, № 2. - С. 30-35.

3. Міні-інвазивні втручання при абсцесах печінки / В. I. Десетирін, О. В. Котов, Т. І. Савченко, Р. Ю. Чечель // Український журнал хірургії. - 2011. - № 3. - С. 179-182.

4. Диагностика и лечение абсцессов печени / Ю. А. Пархисенко, А. А. Глухов, В. В. Новомлинский, И. П. Мшуров // Хирургия. - 2000. - № 8. - С. 33-38.

5. Конькова М. Д. Диагностическая и интервенционная сонография в неотложной абдоминальной хирургии : авто- дартних точок, обов'язково враховуючи анатомію плеврального синуса. Показаннями до цього методу лікування були абсцеси діаметром 3-4 см і більше. Вибір діаметра катетера для адекватного дренування залежав від об'єму порожнини, оскільки в порожнині абсцесу після відбору рідкої частини залишаються секвестри. Тривалість дренування становить від 7 до 29 діб.

У післяопераційному періоді всім пацієнтам обов'язково проводили контрольну УЗД-діагностику для вивчення інволюційних змін залишкових порожнин гнояків. Чітко відмічався кореляційний зв'язок з клінічними і лабораторними показниками захворювання. Тривалість стаціонарного лікування становила від 5 до 16 днів.

Ми отримали дані мікробного пейзажу при АП, вони були такі: Staphylococcus spp, E. Coli, Citrobacter spp, Enterococus spp. Всі пацієнти на початку лікування отримували цефалоспорини III-IV поколінь, аміноглікозиди, фторхінолони. Після отримання чутливості до антибіотиків проводили корекцію призначеної емпіричної антимікробної терапії. Черезшкірне дренування виявилось ефективним у 96,85 \% хворих.

Причиною рецидивів абсцесів у 3 пацієнтів була наявність дрібних секвестрів некротизованої паренхіми печінки, що підтримувало гнійнозапальний процес. Летальності не було.

Висновки. 1. Застосування пункційно-дренажних технологій під контролем УЗД у пацієнтів 3 приводу АП $є$ ефективним методом їх лікування і альтернативою традиційним відкритим хірургічним втручанням.

2. Міні-інвазивні хірургічні втручання забезпечують меншу частоту ускладнень, тривалість госпіталізації, значно покращують якість життя та результати лікування.

реф. дис., на соискание учёной степени доктора мед. наук / М. Д. Конькова. - Донецк, 2007. - 32 с.

6. Машковський Т. Ю. Порівняльна оцінка ефективності відкритих та міні-інвазивних втручань в лікуванні абсцесу печінки та скупчень рідини післяопераційного походження / Т. Ю. Машковський // Клінічна хірургія. - 2012. - № 12.- С. 5-8.

7. Ультразвукова діапевтика абсцесу печінки, можливості і здобутки / М. Ю. Ничитайло, Г. Ю. Машковський, М. В. Костилев, Е. Ю. Лебедева // Клінічна хірургія. - № 10. - С. 12-15. 8. Pyogenic liver abscessi: retrospective, analysis of 80 cases over a 10-year period / W. M. Wong, B. C. Wong, C. K. Hui [et al.] // J. Gastroenterorol. - 2002. - Vol. 17. - P. 1001-1007. 